\title{
Influence of Operation Conditions on Carbon Deposition in SOFCs Fuelled by Tar-Containing Biosyngas
}

Ming Liu, M. G. Millan-Agorio, P.V. Aravind and N.P. Brandon

ECS Trans. 2011, Volume 35, Issue 1, Pages 2701-2712.

doi: 10.1149/1.3570269

Email alerting Receive free email alerts when new articles cite this article - sign up in the service box at the top right corner of the article or click here 


\title{
Influence of Operation Conditions on Carbon Deposition in SOFCs Fuelled by Tar-containing Biosyngas
}

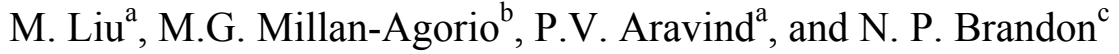 \\ ${ }^{a}$ Process and Energy, Delft University of Technology, $2628 \mathrm{CA}$, Delft, The Netherlands \\ ${ }^{\mathrm{b}}$ Chemical Engineering, Imperial College London, SW7 2AZ, London, UK \\ ${ }^{\mathrm{c}}$ Earth Science and Engineering, Imperial College London, SW7 2AZ, London, UK
}

\begin{abstract}
This paper presents the influence of operation conditions including steam levels, current density and operating time on the performance of Solid Oxide Fuel Cells (SOFCs) fuelled by tarcontaining biosyngas. The performance of SOFCs was evaluated by means of recording impedance spectra and polarization curves of the cells before and after tar exposure. The biosyngas composition and the tar concentration used in the measurements were experimentally measured from a commercial gasifier. The results show that increases steam level and current load would reduce the risk of carbon deposition arising from the tar-containing biosyngas. Deposited carbon was found by the change in impedance and by Scanning Electron Microscopy. SOFCs fed by the biosyngas with a high tar level are not expected to be operated for a long term, because this operation resulted in a severe carbon deposition on the anodes.
\end{abstract}

\section{Introduction}

Due to the sustainable biomass resources and high conversion efficiency of environmentally benign SOFCs, combination of gasifiers with SOFCs is regarded as a promising candidate for renewable power generation. Many authors have reported work with regard to this kind of system (1-5). A challenging problem for successfully utilizing biosyngas from biomass gasification is the presence of contaminants like particulates, tars and some other trace contaminants. These contaminants are detrimental to the gasifierSOFC system. For example, if a high concentration of tars is present in the biosyngas stream for SOFCs, it can lead to gas pipeline blockage, carbon deposition on the anodes, fuel cell performance degradation and costly system maintenance. The amount of carbon deposited on the anode depends upon various factors. These factors include steam fraction of the fuel gas, working temperature, anode material, and current density at which the cell is operating (6). Generally, carbon deposition decreases with the increase of steam concentration and current density. Incorporating other materials into nickel anodes may also reduce carbon deposition. Murray et al. (7) reported the direct electrochemical oxidation of hydrocarbons using Ni-based anodes doped with ceria, no presence of carbon formation was found during the fuel cell tests. Other studies $(8,9)$ showed that precious metal dopents on the Ni-based anode can also decrease the coking propensity. Nevertheless, currently available commercial SOFC systems, e.g. Siemens Alpha unit (10), employ Ni/YSZ anodes in the SOFC stack. So priority was given in this work to explore the interactions of tar-containing biosyngas with Ni/YSZ anodes. 
In terms of the complete gaisifer-SOFC system, the gas cleaning system also has an influence on carbon deposition in SOFCs. The gas cleaning system influences the composition of the clean biosyngas, the steam concentration in particular (10), and the tar concentration in the biosyngas. It is assumed that a gas cleaning system exists that can remove other impurities and can deliver a range of tar concentrations within that explored in this study. The maximum tar level was experimentally measured from a commercial downdraft fixed-bed gasifier (10). The system for the tar measurements is described in the appendix. The measured tar concentration was then used as the maximum tar content in the SOFCs measurements. Since tar is a mixture of hydrocarbons, in the experiments reported here, for simplicity, toluene was selected as the representative tar from biomass gasification.

As described in (6), the impact of tars on SOFCs can be nullified if proper operation conditions are under control. The information obtained from this experimental evaluation gives an indication of the expected carbon deposition when tar-containing biosyngas is fed to SOFCs. This can help decide if any of tar elimination methods are required for the SOFC system when connected to a biomass gasifier, and to what extent the tar needs to be cleaned. This paper presents the experimental results indicating the influence of operating conditions on carbon deposition in SOFCs fed by tar-containing biosyngas.

\section{Experimental}

\section{$\underline{\text { Sample Preparation }}$}

Electrolyte supported SOFCs were prepared in order to assess anode performance under varying load and steam conditions in the presence of tar-containing biosyngas. All samples used were made in the same batch, such that screen printing and sintering of the anode and cathodes were done at the same time in identical conditions, to reduce variability in cell preparation. The method used for preparing the SOFCs with Ni/YSZ anodes has been described previously $(3,11)$ and is briefly outlined here. Yttria-stabilized zirconia (YSZ) pellets were prepared by pressing 3 grams YSZ (TZ-8Y Zirconia, Tosoh Corporation) powder at 1 Tonne pressure for $25 \mathrm{~s}$, then the pellets were sintered at $1450^{\circ} \mathrm{C}$ for 5 hours at a ramp rate of $5^{\circ} \mathrm{C} / \mathrm{min}$. After sintering, the pellets were polished using rough and fine polish paper consecutively to ensure a uniform thickness of $\sim 1.3$ $\mathrm{mm}$ circular prior to screen printing the anode and cathode on the electrolyte. Nickel oxide cermet ink (60:40 NiO/YSZ by weight) for the anode, and LSM-YSZ (50:50 ( $\mathrm{La}_{0.80}$ $\left.\mathrm{Sr}_{0.20}\right)_{0.98} \mathrm{MnO}_{3-\mathrm{x}} /\left(\mathrm{Y}_{2} \mathrm{O}_{3}\right)_{0.08}\left(\mathrm{ZrO}_{2}\right)_{0.92}$ by weight $)$ for the cathode and reference electrode, were screen printed with 2 passes through a 325 mesh count screen. After each printing, the pellets were dried for few hours and then fired sequentially at $1300^{\circ} \mathrm{C}$ for the anode and $1150^{\circ} \mathrm{C}$ for the cathode for $1 \mathrm{~h}$ respectively. The anode was a circular disk with diameter around $1.1 \mathrm{~cm}$ and thickness about $60 \mu \mathrm{m}$. The anode surface area is about 0.95

$\mathrm{cm}^{2}$. The cathode was an identical circular disk, surrounded by a reference cathode. The internal diameter of the reference cathode is $17 \mathrm{~mm}$ and the external diameter is $19 \mathrm{~mm}$. A view of the sample is shown in figure 1.

\section{$\underline{\text { Experimental Procedure }}$}

The fuel cells were tested in a button fuel cell test unit. A detailed description of this fuel cell test unit was given in (11). The cell was taken up to an operating temperature of 


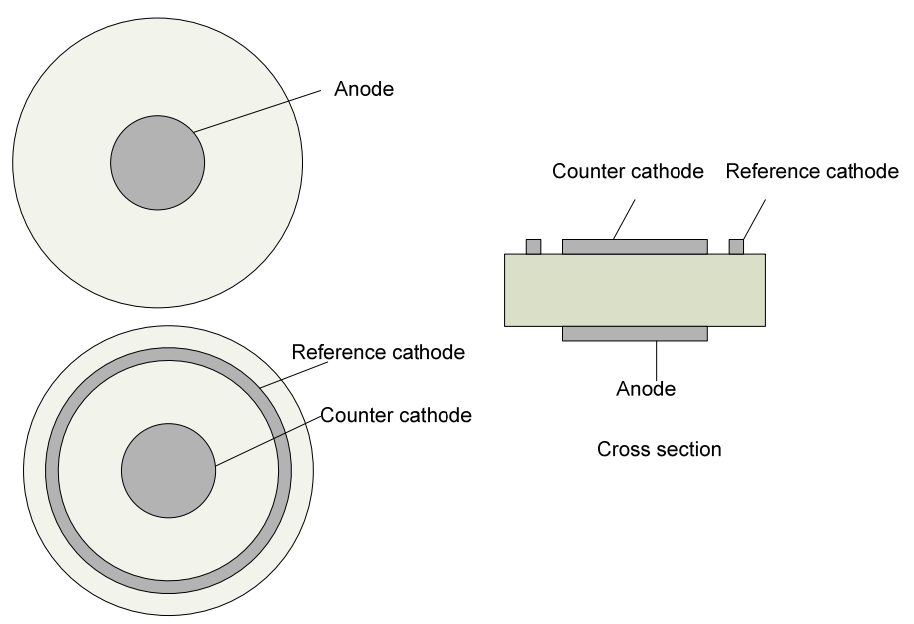

Figure 1. 3-electrode fuel cell samples (not in scale).

$800^{\circ} \mathrm{C}$ at a ramp rate of $7.5^{\circ} \mathrm{C} / \mathrm{min}$ with the anode side exposed to an inert atmosphere of $\mathrm{N}_{2}$. Before tar was introduced, the gas pipeline was trace heated above the boiling point of the tar, and the temperatures at various points were monitored as shown in figure 2 . When a stable operation temperature of $800^{\circ} \mathrm{C}$ reached, anode reduction took place by exposing it to $2.5 \%$ humidified steam and $5 \% \mathrm{H}_{2}$ balance $\mathrm{N}_{2}$ for 30 minutes, then increasing incrementally to $25 \% \mathrm{H}_{2}$ balance $\mathrm{N}_{2}$ over a period of 30 minutes at a flow rate of $50 \mathrm{ml} / \mathrm{min}$. The sample was then held in $25 \% \mathrm{H}_{2}$ for 30 minutes. After reduction, the flow was increased to $100 \mathrm{ml} / \mathrm{min}$ and the hydrogen concentration was changed to the experimental operation conditions of the biosyngas. Initial fuel cell performance was recorded as a reference at each condition before introducing tar, and then the tar injector pump was started to inject tar into the biosyngas stream for $45 \mathrm{~min}$. After the tar injection, the electrochemical performance of the sample was measured again. For the electrochemical measurements, an Autolab PGSTAT302 (Eco Chemie BV, The Netherlands) with an FRA module was used. The electrochemical impedance response was measured in the frequency range $0.1 \mathrm{~Hz}$ to $10 \mathrm{kHz}$ with five points measured at each decade, and stimulus potential amplitude of $0.02 \mathrm{~V}(\mathrm{rms})$ was used throughout. Voltage current performance was measured from open circuit $(0 \mathrm{~A})$ to an applied current of $0.2 \mathrm{~A}$, with a step current of $0.00015 \mathrm{~V}$ and a scan rate of $0.02 \mathrm{~A} / \mathrm{s}$. Nova 1.5 software was used to $\log$ and analyze the measurements. After each measurement, the fuel cell test rig was cooled down using $15 \% \mathrm{H}_{2} / \mathrm{N}_{2}$ mixture to the room temperature under a dry condition. A schematic view of the fuel cell test station is given in figure 2 .

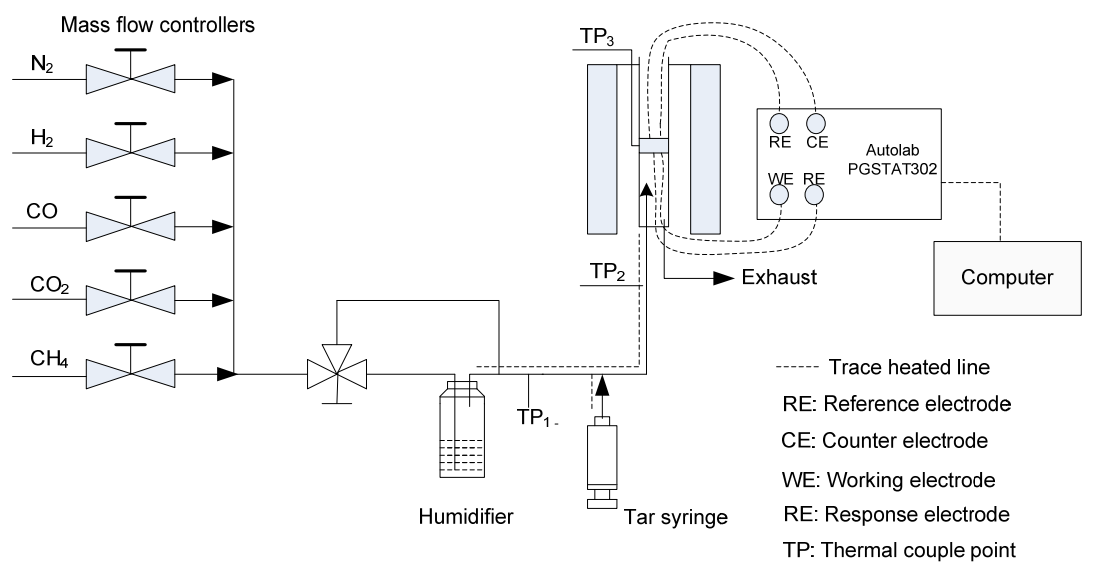

Figure 2. A schematic view of the SOFC test station. 
In this work, performance curves are expressed for anode potential, measured as the uncorrected potential difference between the anode and reference electrode (12), as a function of current density. Discussions on the correction method for the anode potential of this three-electrode fuel cell were further explained in (13).

\section{Working Conditions}

Different clean biosyngas compositions are obtainable by mixing those gas components regulated by mass flow controllers shown in figure 2 . Steam content can be varied by controlling the water temperature of a water bath. The gas stream was humidified by passing the outlet of the gas line through a water bubbler, which is located in the water bath. The maximum tar level used in the fuel cell measurements is slightly higher than that experimentally measured. Working conditions for the evaluation of the SOFC performance are given in table I.

TABLE I. Working Conditions Used in Fuel Cell Performance Measurements

\begin{tabular}{cc}
\hline Conditions & Value \\
\hline Average dry gas composition $(\%)$ & $16 \mathrm{H}_{2}, 1.5 \mathrm{CH}_{4}, 46.5 \mathrm{~N}_{2}, 16 \mathrm{CO}_{2}, 20 \mathrm{CO}$ \\
Steam level $(\%)$ & $0-10$ \\
Tar level $\left(\mathrm{g} / \mathrm{Nm}^{3}\right)$ & $0-6.3$ \\
Temperature $\left({ }^{\circ} \mathrm{C}\right)$ & 800 \\
\hline
\end{tabular}

\section{Results and Discussion}

\section{$\underline{\text { Fuel Cell Open Circuit Voltage }}$}

Open circuit voltage (OCV) over time during reducing process is plotted in figure 3. It is recommended to reduce the anode in an increasing hydrogen concentration under wet conditions rather than at a constant high hydrogen content $(>25 \%)$. This is mainly because the improper dispersion of nickel and YSZ particles within the ink could lead to increased sintering and agglomeration of nickel under such a high $\mathrm{H}_{2}$ concentration (12), and resulting in further cell degradation in later measurements. Dry reduction conditions can result in increased degradation. King et al. (14) suggested that a high steam concentration $(>75 \%)$ within the reducing gas would prolong the reduction process, the optimum steam concentration for the anode reduction still needs to be explored. After the reduction procedure, the OCV of the cell in this test unit was around $0.99 \mathrm{~V}$ showing a reasonable agreement with the theoretical value $1.03 \mathrm{~V}$ under the working conditions of $15.6 \% \mathrm{H}_{2} / 2.5 \%$ steam $/ \mathrm{N}_{2}$ at $800^{\circ} \mathrm{C}$. The slight difference may because of the following as explained in $(12), 1)$ the possible errors in actual $\mathrm{H}_{2}$ flow rate due to dilution with steam concentrations, 2) actual steam concentrations may have been higher than calculated, and 3) there could be the possibility of a small leak in the seal connecting the anode side of the fuel cell with the test rig.

Figure 4 shows the representative SEM image for the anodes of the cells after the reduction, a homogeneous microstructure was observed in the cell. The cell was reduced at $800^{\circ} \mathrm{C}$ with increasingly elevated hydrogen concentrations. 


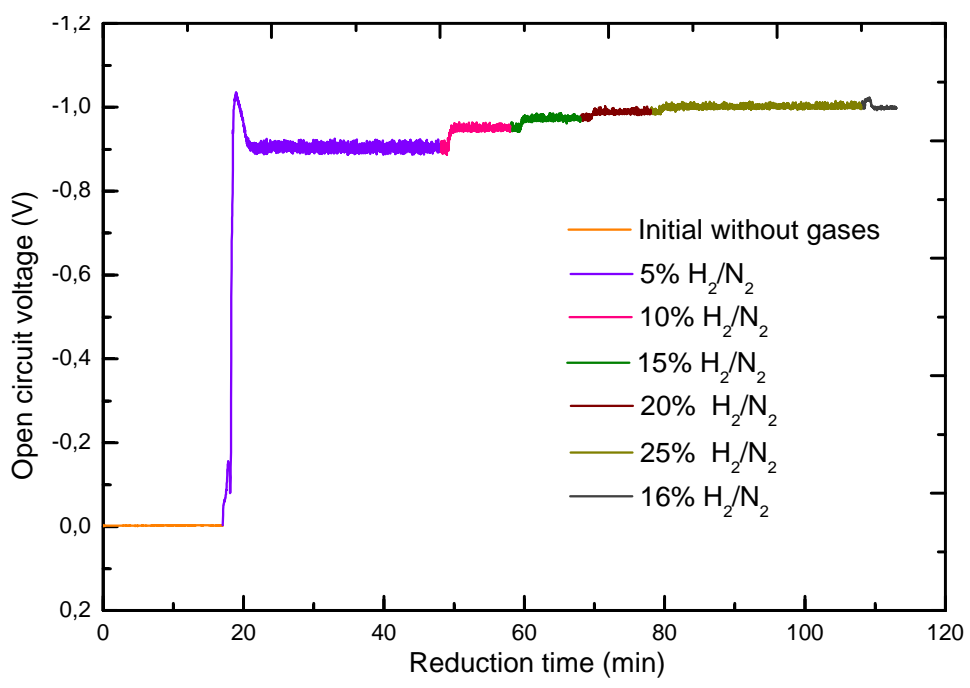

Figure 3. OCV over the time of reduction using various reducing gases with $2.5 \%$ steam.

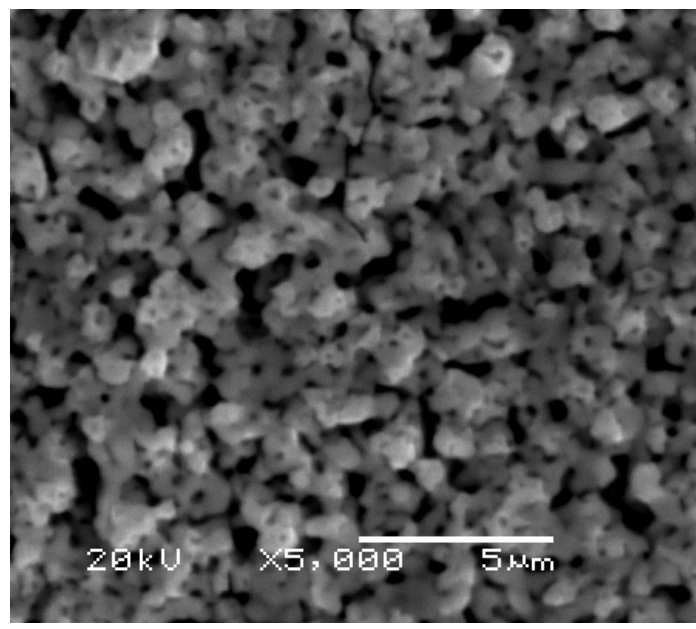

Figure 4. Image of the fuel cell sample after reduction ( $\times 5000$ magnification).

\section{Effect of Steam Content in Biosyngas on Cell Performance}

The steam concentration has a significant influence on inhibiting the deposition of carbon when the fuel cell is fed by tar-containing fuel gas (3). As the steam level within the clean biosyngas can typically lie in the range of 2.5 to $30 \%$ (10), the possibility of carbon deposition from the tar-containing biosyngas was evaluated thermodynamically. The tar concentration was $6.3 \mathrm{~g} / \mathrm{Nm}^{3}$. The thermodynamic tool, Factsage 5.3 (15) was used for this calculation; results are given in figure 5 .

As shown in figure 5, the amount of solid carbon $(\mathrm{C}(\mathrm{s}))$ reached a maximum under dry conditions, accounting for $7 \%$ molar of the inlet fuels. It decreased with steam concentration, falling to zero at a steam level of $10 \%$. For the current gas composition and operating conditions, we consider this as a threshold steam level. Solid carbon is therefore not thermodynamically favored when the steam concentration is over this threshold concentration of $10 \%$, which is a typical water vapor value within the raw biosyngas from the gasifier described in (10). This indicates that the biosyngas from the gasifier may be directly supplied to the SOFC operated at open circuit if other contaminants can be properly removed. 


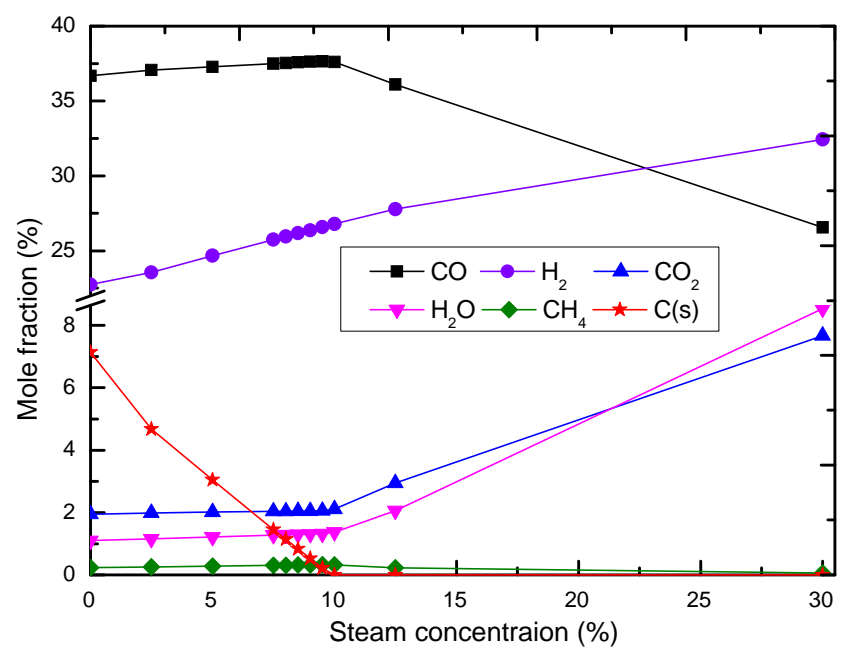

Figure 5. Influence of steam concentration on carbon formation arising from the tarcontaining biosyngas in SOFCs operated under $\mathrm{OCV}$ at $800^{\circ} \mathrm{C}$.

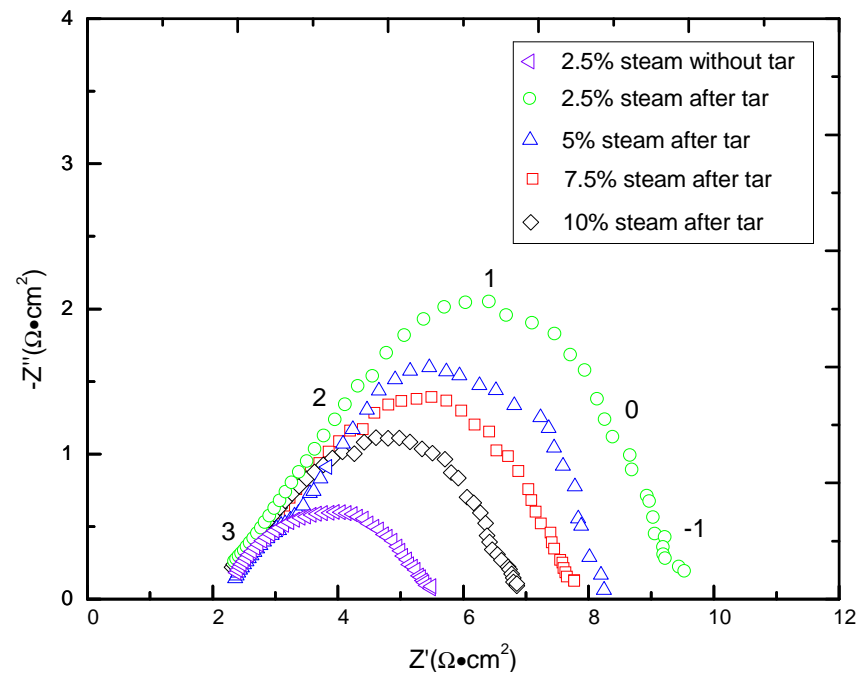

Figure 6. Impedance spectra of SOFCs fed by biosyngas with $6.3 \mathrm{~g} / \mathrm{Nm}^{3}$ tar in humidified steam for $45 \mathrm{~min}$. Log scale frequencies are presented next to the $2.5 \%$ steam fraction plot after tar exposure.

This is an agreement with the changing impedance arcs measured after tar exposure under various steam levels shown in figure 6. No significant change of impedance spectra was found in SOFCs fed by the biosyngas with various steam fractions before tar exposure. Burnette et al. (16) has reported a similar observation. The impedance spectrum of SOFC measured at the condition with $2.5 \%$ steam was selected as the reference before tar exposure tar. The average series resistance under various steam fractions was around $2.2 \Omega \bullet \mathrm{cm}^{2}$, while the average initial polarization impedance was 3.4 $\Omega \cdot \mathrm{cm}^{2}$. Average cell degradation rates were observed at $0.25 \mathrm{ohm} \cdot \mathrm{cm}^{2} / \mathrm{hr}$ and 0.55 $\mathrm{ohm} \cdot \mathrm{cm}^{2} / \mathrm{hr}$ for the series resistance and the polarization impedance respectively at the condition without tar. The size of the impedance arc decreased with increasing steam fraction of the biosyngas after tar exposure, indicating the increased steam inhibited carbon deposition. The increase in polarization impedance when tar was added is clear in this figure. At a steam content of $10 \%$ within the biosyngas in the SOFC operated at a current density of $150 \mathrm{~mA} / \mathrm{cm}^{2}$ carbon deposition still occurred, reflected by the increased polarization impedance compared to the initial condition. 


\section{$\underline{\text { Effect of Current Density }}$}

Oxygen ions, transferred through electrolyte from cathode to anode, can reduce the risk of carbon deposition. This may because of partial tar oxidation and/or carbon oxidation when current is drawn from the fuel cell. The effect of current density on carbon formation predicted by thermodynamic calculation (oxygen diffusion gradient was not considered) is shown in figure 7. The amount of deposited carbon is decreasing with the increase of current density. When further increasing the current density over 950 $\mathrm{mA} / \mathrm{cm}^{2}$, carbon formation is not thermodynamically favored. However, cell degradation becomes more significant under such a high current density that inhibits the deposition of carbon. For example, Muller et al. (17) set a high current density in a range of 200-600 $\mathrm{mA} / \mathrm{cm}^{2}$ on single cells and found agglomeration of the nickel particles was apparently observed in all tested anodes. This suggests that the biosyngas with low steam but high tar level as considered here is not suitable for directly feeding to SOFCs in practical applications.

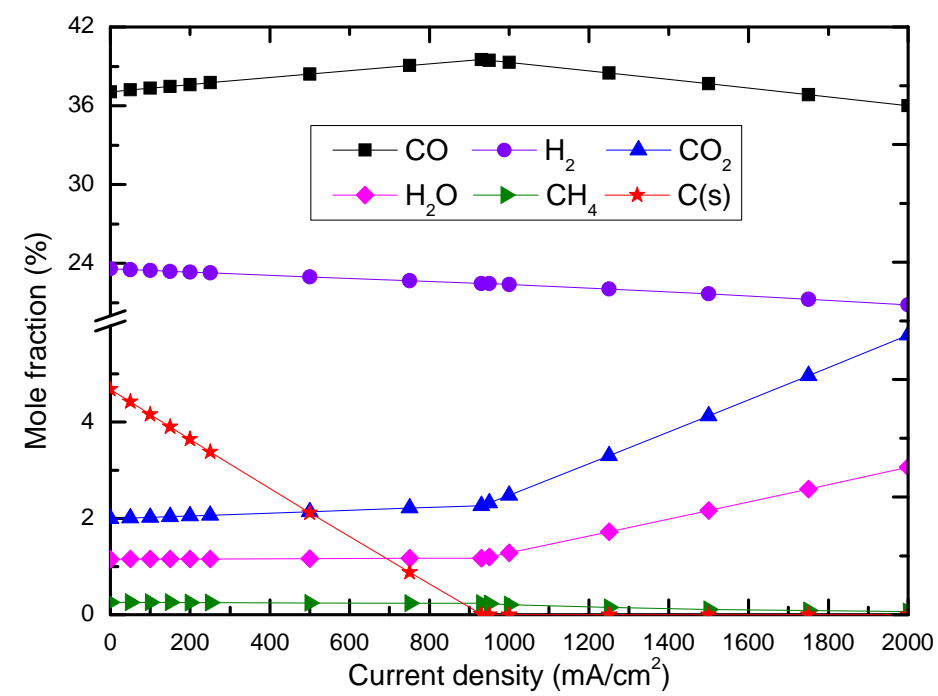

Figure 7. Thermodynamic prediction of the influence of current density on carbon formation resulted from biosyngas with $2.5 \%$ steam and $6.3 \mathrm{~g} / \mathrm{Nm} 3$ tar on the SOFC operated at $800^{\circ} \mathrm{C}$.

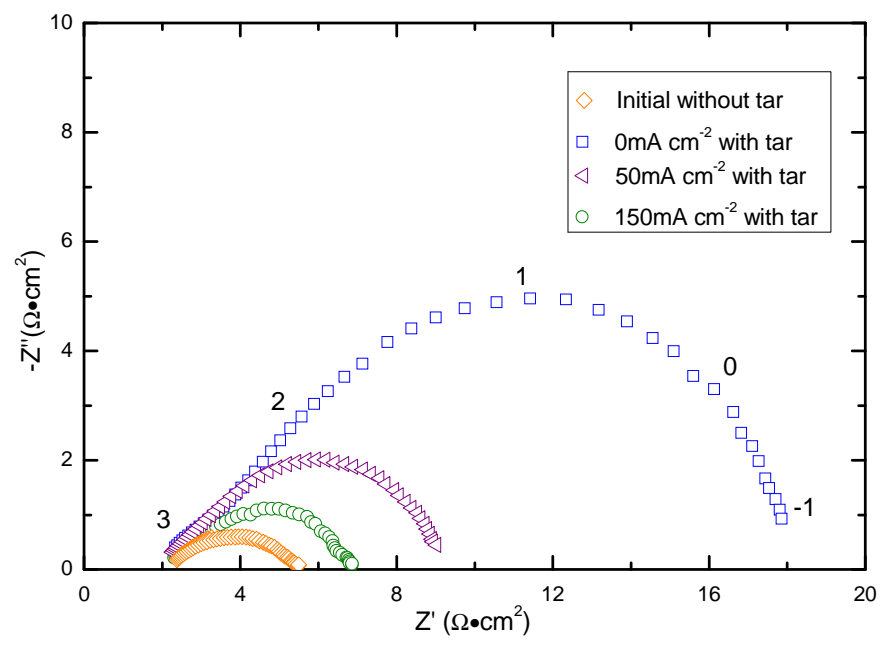

Figure 8. Influence of current density on the impedance spectra of SOFCs fed with biosyngas with $10 \%$ steam and $6 \mathrm{~g} / \mathrm{Nm} 3$ tar at $800^{\circ} \mathrm{C}$. 
The effects of increasing current density on carbon deposition arising from the tarcontaining biosyngas were experimentally investigated and the recorded spectra are given in figure 8. Impedance spectra of the cell had a larger arc when operated with the tarcontaining biosyngas at open circuit. When the cell load was increased to $150 \mathrm{~mA} / \mathrm{cm}^{2}$, carbon deposition still occurred compared to the condition without tar, but at a lower rate. This is observed from the change of the impedance arc. At higher current loads, the impedance decreased and approached the values without tar. The most severe carbon deposition was at open circuit. It is expected that further increasing the current load would further decrease the risk of carbon deposition. This is also reflected in the polarization curves measured at OCV of separate Ni/YSZ anodes after exposure to 6.3 $\mathrm{g} / \mathrm{m}^{3}$ tar for 45 minutes at 0 and $50 \mathrm{~mA} / \mathrm{cm}^{2}$. The initial cell performance before tar exposure was also measured. The polarization curve is given in figure 9 . The increase in current density increases the concentration of $\mathrm{O}^{2-}$ ions at the anode. This probably allows the partial oxidation of carbonaceous species and the oxidation of deposited carbon. After tar exposure, the polarization curves show the negative impact on the anode reaction. This impact is reduced by operating the cell under a load of $50 \mathrm{~mA} / \mathrm{cm}^{2}$ compared to running the cell at OCV. Mermelstein et al. (3) presented similar observations with regard to the effect of current density on the carbon deposition when benzene was used as the tar in the mixture $\mathrm{H}_{2} / \mathrm{N}_{2}$ for SOFCs. Mass transport in the polarization curves didn't appear at the load of $50 \mathrm{~mA} / \mathrm{cm}^{2}$ but appeared to be present at the OCV.

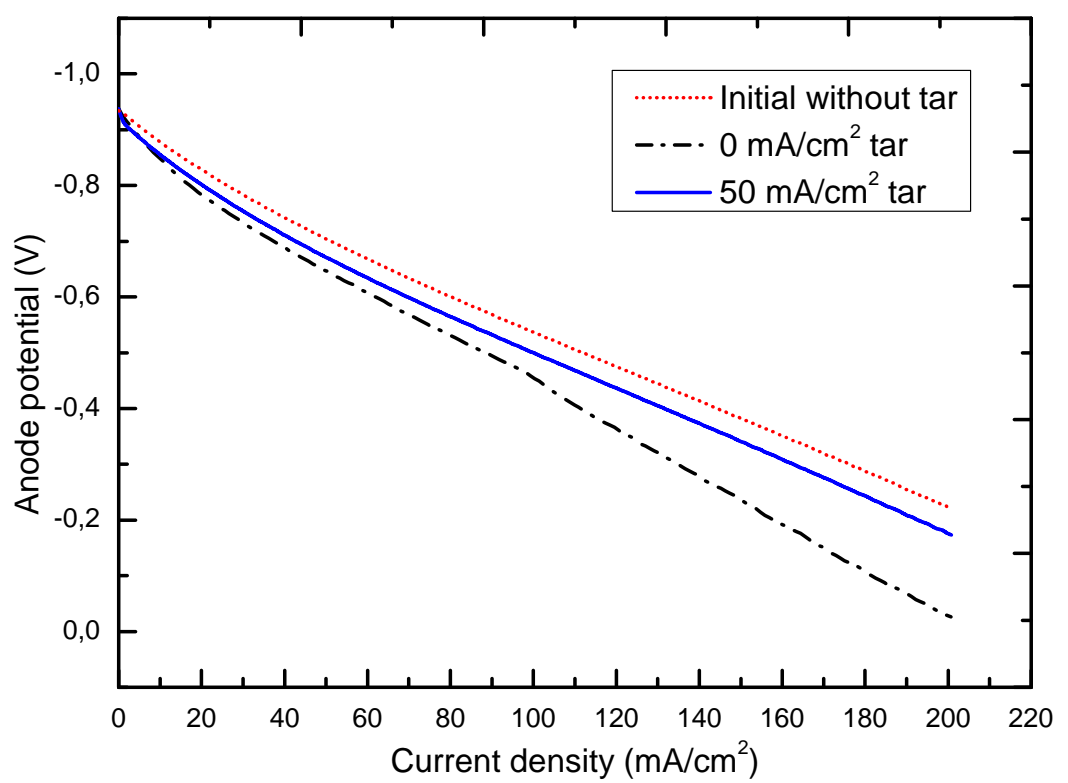

Figure 9. Anode polarization of SOFC fuelled by biosyngas with $10 \%$ steam and 6.3 $\mathrm{g} / \mathrm{m}^{3}$ tar after operating at 0 and $50 \mathrm{~mA} / \mathrm{cm}^{2}$ for 45 minutes.

\section{$\underline{\text { Long Term Operation with Tar Containing Biosyngas }}$}

Previous discussions have shown that in a short term operation (45 min), carbon formation on the SOFCs resulted from the tar-containing biosyngas can be reduced by means of increasing steam concentration and current load, however the longer term effects ( $\sim 5$ hours) of tar exposure on the anode are not well known. Separate fuel cells with Ni/YSZ anodes operated at $100 \mathrm{~mA} / \mathrm{cm}^{2}$ were tested for 5 hours. The biosyngas with $6.3 \mathrm{~g} / \mathrm{Nm}^{3}$ tar and $10 \%$ steam was used as the fuel. Even at a relatively high current load and a high steam fraction, carbon deposition was experimentally found from both the 
impedance characteristics and the microstructure of the anode after tar exposure. Carbon deposition continuously occurred at exposure times up to 5 hours. This is reflected in the impedance change shown in figure 10 and in the polarization curves shown in figure 11 . After 5 hours' tar exposure, carbon significantly deposited on the anodes as shown in figure 12. Mass transport seems to become a factor after 5 hours' tar exposure at higher current densities $\left(>120 \mathrm{~mA} / \mathrm{cm}^{2}\right)$ in the polarization curve due to the carbon deposits. It was found that the OCV slightly increased. This may attribute to the following possibilities, 1) catalytic decomposition of tar into carbon and hydrogen that increase the $\mathrm{H}_{2}$ partial pressure, 2) the deposited carbon may create a direct carbon fuel cell that has a slightly higher thermodynamic standard potential than the biosyngas at $800^{\circ} \mathrm{C}$ and 3 ) steam reforming of tar and/or methane may occurred that increases the OCV. The former two possibilities were also suggested in (11) and the third one, the possibility of tar reforming at SOFC anodes, was suggested in (4) and (18).

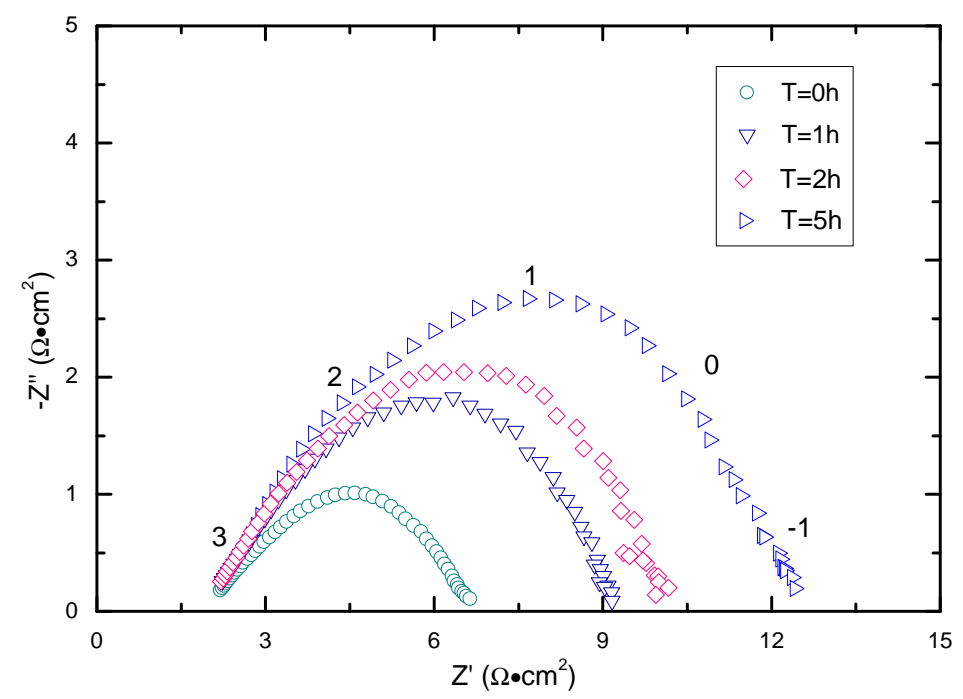

Figure 10. Impedance spectra of SOFC fuelled by biosyngas with $6.3 \mathrm{~g} / \mathrm{Nm}^{3}$ tar and $10 \%$ humidified steam for 5 hours under a load of $100 \mathrm{~mA} / \mathrm{cm}^{2}$ at $800^{\circ} \mathrm{C}$.

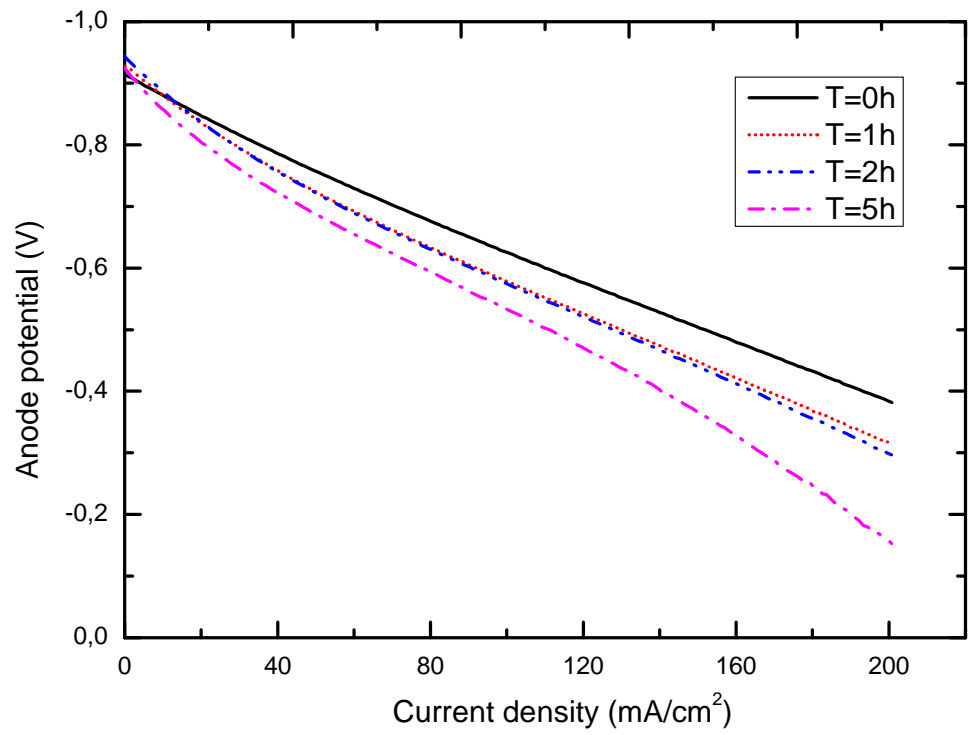

Figure 11. Anode polarization curves of the SOFC during 5 hours' tar exposure. 


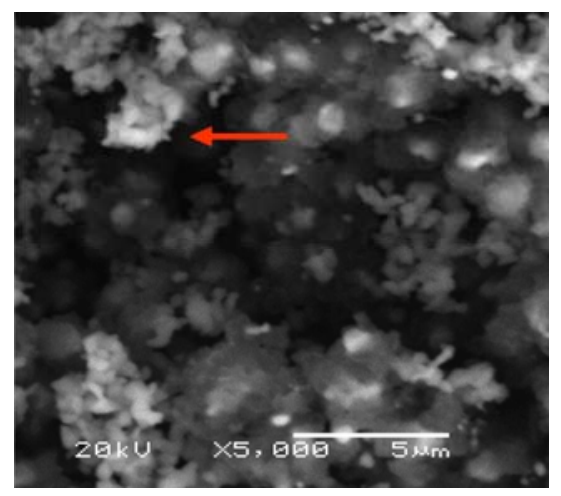

Figure 12. Image of anode microstructure with carbon deposition (arrow direction) after 5 hours' tar exposure.

\section{Conclusion}

The influence of tar-containing biosyngas on SOFCs with Ni/YSZ anodes under varied working conditions in terms of steam fraction of the fuel gas, current density of the cell and operation time was experimentally investigated. Carbon deposition caused by the tar can be clearly seen from the changes of impedance spectra and polarization behavior. It is found that increased steam content and higher current load reduced the risk of carbon deposition arising from the tar-containing biosyngas. This is consistent with the thermodynamic predictions. However, carbon deposition occurred under conditions which are not thermodynamically favored. The biosyngas with $10 \%$ steam and $6.3 \mathrm{~g} / \mathrm{Nm}^{3}$ tar cannot be directly fed to the SOFCs under the conditions employed in this study. Therefore SOFCs with Ni/YSZ anodes operated for the long term causes severe carbon deposition and degrades the SOFC significantly. Therefore, a suitable gas cleaning unit is required to reduce the tar level in the biosyngas if it is to be fed to SOFCs under the conditions considered here.

\section{Acknowledgments}

Prof. A.H.M. Verkooijen, from Delft University of Technology, The Netherlands, is thanked for his support and advice. We also thank Prof. V.R.M. Cobas, Dr. R.V. Andrade and S.Y.G. Restrepo from Federal University of Itajuba, Brazil for their support and help on the tar measurements. IDEA League is thanked for partial financial support for this work through the IDEA League student grant scheme.

\section{References}

1. P.V. Aravind, T. Woudstra, N. Woudstra, and H. Spliethoff, J. Power Sources, 190 (2009).

2. A.O. Omosun, A. Bauen, N.P. Brandon, C.S. Adjiman, and D. Hart, J. Power Sources, 131 (2004).

3. J. Mermelstein, M. Millan, and N. Brandon, J. Power Sources, 195 (2010).

4. P.V. Aravind, J.P. Ouweltjes, N. Woudstra, and G. Rietveld, Electrochem. SolidState Lett., 11 (2008). 
5. J.P. Ouweltjes, P.V. Aravind, N. Woudstra, and G. Rietveld, J. Fuel Cell Sci. Technol. 3 (2006).

6. D. Singh, E. Hernández-Pacheco, P.N. Hutton, N. Patel, and M.D. Mann, J. Power Sources, 142 (2005) .

7. E.P. Murray, T. Tsai, and S.A. Barnett, Nature, 400 (1999).

8. S. McIntosh, J.M. Vohs, and R.J. Gorte, J. Electrochem. Soc., 6 (2003).

9. T. Takeguchi, R. Kikuchi, T. Yano, K. Eguchi, and K. Murata, Catal. Today, 84 (2003).

10. M. Liu, P.V. Aravind, T. Woudstra, V.R.M. Cobas, and A.H.M. Verkooijen, in proceedings of $9^{\text {th }}$ European fuel cell forum, Lucerne, Switzerland (2010).

11. J. Mermelstein, M. Millan, and N.P. Brandon, Chem. Eng. Sci., 64 (2009).

12. J. Mermelstein, PhD thesis, Imperial College London, 2009.

13. G.J. Offer, P. Shearing, J.I. Golbert, D.J.L. Brett, A. Atkinson, and N.P. Brandon, Electrochim. Acta, 53 (2008).

14. D.L. King, J.J. Strohm, X. Wang, H. Roh, C. Wang, Y. Chin, Y. Wang, Y. Lin, R. Rozmiarek, and P. Singh, J. Catal., 258 (2008).

15. Factsage 5.4.1, www.factsage.com

16. D.D. Burnette, G.G. Kremer, and D.J. Bayless, J. Power Sources, 182 (2008)

17. A. Müller, A. Weber, H.J. Beie, A. Krügel, D. Gerthsen, and E. Ivers-Tiffée, in proceedings of the $3^{\text {rd }}$ European Solid Oxide Fuel Cell Forum, Nantes, France, (1998).

18. P.V.Aravind, PhD thesis, Delft University of Technology, 2007. 


\section{Appendix}

An in-situ system for measuring the concentration of tar from a downdraft fixed-bed gasifier was used as shown in figure A1. This gasifier uses air as the gasifying agent and has two-stage air supply. The biomass fuel is fed from the upper part while the produced raw biosyngas is emitted from the lower part. More details about this gasifier were given elsewhere (10). When a stable gasification performance (reflected from relatively stable gas compositions read from online gas analyzers (Rosemount BINOS 100 and HYDROS 100)) was achieved, a split stream of the raw biosyngas from the gasifier was introduced to the tar measurement system. This system included several components. The first part was a filter wrapped with a mental casing. The casing was electrically heated and the temperature of the casing was kept above $200{ }^{\circ} \mathrm{C}$ to avoid tars condensation. This installation can ensure particulates-free gas which then flowed to the impingers. There were total six impingers, five of which were filled with isopropyl alcohol and the other one at the final stage was empty. All the impingers were located in the ice-filled vessel, to ensure that all the tar can be captured. The volume of the sampled gas was measured by the downstream gas flow meter. The sample time was lasted for an hour when the gasifier was running in a steady state and then was ceased by switching the bypass valve for the sampling gas off. Standard post-analysis method was employed to determine the tar concentration. The filter was first taken out from the installation and then was put into a Soxhlet unit to extract the possible condensed tar on the filter. After several times of extractions, the mixture in the Soxhlet unit and the solution from impingers were collected in a flask. The flask was then evaporated in a rotary evaporator system located in a temperature controlled water bath. After few hours' evaporation, the flask was put in a drier set at $130{ }^{\circ} \mathrm{C}$ for 1 hour. The left material in the flask was regarded as the tar which was then balanced to determine the weight. The tar concentration was determined by the weighed tar together with the sample gas volume. The maximum tar concentration after several measurements was around $6 \mathrm{~g} / \mathrm{Nm}^{3}$. This value of the tar concentration was then used as the maximum tar content in the SOFC measurements.

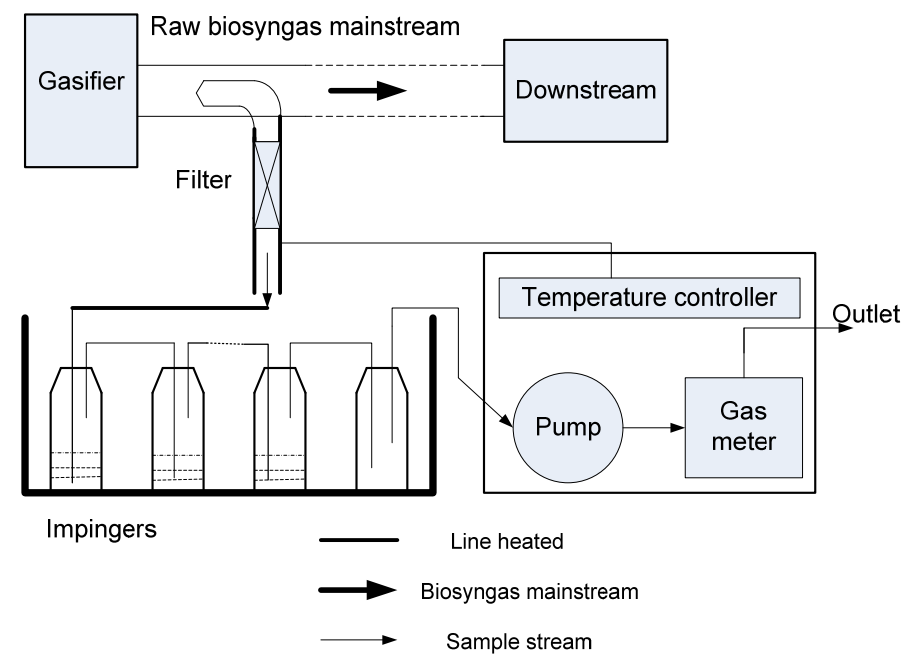

Figure A1. Tar concentration measurement system 